\title{
THE DOCTRINE OF SEPARABILITY OF ARBITRATION CLAUSE IN COMMERCIAL ARBITRATION REVISITED
}

\author{
Miftahul Huda*
}

\section{Abstract}

This article reassesses the doctrine of sepaparability of arbitration clause contained in the contract whether constituted separate or autonomous contract absolutely. This separability of arbitration clause doctrine adopted and regarded as trend particularly in international arbitration to prevent bad attempts by a (disputing) contracting party to obstruct the arbitral proceeding by alleging invalidity of the main contract. If so the valuable advantages of arbitration will be derogated. This article examines the autonomous position of arbitration clause in its related contract practically and theoretically justified and reflected by the current international arbitration conventions and rules. Its application of this doctrine of separability of arbitration clause is to further strengthen the objective of arbitration. However, the author finds and concludes that separating arbitration clause from an allegedly nonexistent agreement strains logic because arbitration is rooted in consent or agreement.

Key words: separability, arbitration clause, party autonomy

\section{Introduction}

The legal nature of an arbitration clause in relation to the contract from which it originates has been widely debated in recent years. In reality, the problem arises more for the arbitration clauses than for submission agreement, which is at least a physically separate contract. It has been argued at the length whether arbitration clauses must follow the destiny of the contract to which they form part, or whether they can have an independent life.

The modern trend in international arbitration is to regard an arbitration clause in a contract as constituting a separate and autonomous contract.

* Senior Lecturer in Commercial Arbitration, Faculty of Law, The University of Indonesia. Alamat korespondensi: hudanco@yahoo.com. 
Under this concept, known as the doctrine of separability, ${ }^{2}$ an assertion that the main contract is alleged invalid does not prevent the arbitrators from ruling on the validity of the arbitration clause contained therein. This doctrine of separability has been widely accepted in the field of international commercial arbitration as to contracts which have been validly entered into, whose continuing validity is disputed ${ }^{3}$ for reasons of breach, termination, frustration, subsequent invalidity or performance.

However, it is unclear whether the doctrine of separability of an arbitration clause in a contract which is alleged to be invalid or void ab initio for reasons such as illegality, duress, fraud or public policy, has been accepted in international commercial arbitration. Moreover, it is more doubtful whether this separability concept of an arbitration clause in a contract which is alleged to be nonexistent, for example where there has not been a 'meeting of minds,' has been accepted.

This article will examine the current status of the doctrine of separability of an arbitration clause, with special focus on the treatment of arbitration clauses contained in contracts alleged to be void ab initio and nonexistent. It will consider international conventions, rules and cases, and will include a survey of national rules and cases of some of the more important arbitration jurisdictions.

This paper consists of five sections. Section I is an introduction. Section II discusses the arbitration agreement, validity of the arbitration agreement, including the forms or types and the functions of arbitration agreements. Section III discusses the doctrine of separability, its foundation and purposes, some important international conventions and rules, as well as national rules and cases of some important arbitration jurisdictions which support and accept the separability concept. Section IV analyses the doctrine of separability of an arbitration clause contained in contracts which are alleged to be void $a b$ initio and nonexistent. The conclusion is contained in Section V.

1 Alan Redfern and Martin Hunter, "Law and Practice of International Commercial Arbitration”, $2^{\text {nd }}$ ed, (London: Sweet \& Maxwell, 1991), p. 275.

${ }^{2}$ Sometimes it is referred to as the autonomy or severability of the arbitration clause.

${ }^{3}$ Stephen M. Schwebel, "International Arbitration: Three Salient Problems", (Cambridge: Grotius Publication Limited, 1987), p. 2. 


\section{The Agreement to Arbitrate}

\section{A. Arbitration Agreement}

An arbitration agreement can be defined as a provision whereby the parties agree to use arbitration to determine disputes which may arise out of their particular contractual relationship or to resolve an existing dispute between them.

The agreement to submit disputes to arbitration is governed by 'two intertwining principles': party autonomy, or the freedom to contract, and the contractual nature of the agreement. Party autonomy gives contracting parties the power to conclude any terms of contract, including to fashion their own remedial process within the limits of mandatory rules - public policy. ${ }^{5}$

The contractual element of the arbitration agreement rests with the bargain. Both parties to the contract must arrive at a mutually satisfying result, assuming they have equal bargaining positions. Furthermore, in order for a court to recognise an arbitration agreement as valid, it must comply with the established rights and obligations of contracting parties, which are authorised by law.

\section{B. Functions}

The arbitration agreement is the foundation stone of commercial arbitration. It fulfils several important functions. ${ }^{6}$ The first and the most vital function of an arbitration agreement in the present context is that it shows that the parties have consented to resolve disputes by arbitration. It establishes the obligation to arbitrate. This element of consent is essential, because, without it there can be no valid arbitration. ${ }^{7}$ Once parties have validly given their consent to arbitration, this consent cannot be unilaterally withdrawn.

${ }^{4}$ Julian DM. Lew, "Arbitration Agreements: Form and Character", in Petar Šarcevīc (ed), "Essay on International Commercial Arbitration", (London: Graham \& Trotman/ Martinus Nijhoff, 1989), p. 51.

${ }^{5}$ Atiyah, "Essays on Contract", (1986), p. 360.

${ }^{6}$ See generally Redfern and Hunter, above n 1, 5-6.

${ }^{7}$ There are circumstances in which arbitration may be a compulsory method of resolving disputes. Domestically, arbitration may take place compulsory under legislation governing, for instance, labour disputes. Internationally, compulsory arbitrations take place 
Secondly, the arbitration agreement is also the basic source of the powers of the arbitrators. In principle, an arbitral tribunal or an arbitrator may only exercise such powers as the parties confer upon it. The parties to an arbitration are 'masters of the arbitral process" extent impossible in proceedings in a court of law. For instance, the parties may decide the number of arbitrators to comprise the arbitral tribunal, how it should be appointed, what powers it should possess, and what procedure it should follow. The arbitral tribunal owes its existence to the agreement of the parties. If the parties are in agreement, the arbitrators must follow their reasonable requirements.

Finally, an arbitration agreement establishes the jurisdiction of the arbitral tribunal. The arbitration agreement is the only source from which this jurisdiction can come. It is different to the ordinary legal process whereby disputes are resolved through the public courts, where jurisdiction may come from several distinct and different sources, of which an agreement by the parties to submit to the jurisdiction will be only one. In the arbitral process, which is a private method of resolving disputes, the jurisdiction of the arbitral tribunal is derived solely from the agreement of the parties.

\section{Forms}

There are two basic forms of arbitration agreement. ${ }^{9}$ One contemplates the settlement of an existing dispute, and is generally called a 'submission to arbitration agreement' or simply, a 'submission agreement. ${ }^{10}$ The other relates to future dispute, in which the parties

between trading agencies of socialist countries under the Moscow Convention on the Settlement by Arbitration of Civil Law Disputes Resulting from Economic, Scientific and Technological Cooperation, 1972. However, compulsory arbitration is outside the scope of this paper.

${ }^{8}$ Redfern and Hunter, above n 1,6 .

${ }^{9}$ Although, in the modern statutes and judicial decisions, the difference between them tends to be blurred to a significant extent, all systems of law acknowledge the existence of the two types of arbitration agreement. Even a number of Latin American countries continue to make the distinction. However, as a practical matter, it is to be noted that the issue occasionally surges to the surface in the form of a plea of invalidity of arbitration clauses referring to future disputes. See Georges R. Delaume, "Law and Practice of Transnational Contracts”, (New York: Oceana Publications, Inc, 1988), p. 284.

${ }^{10}$ In civil law, such a submission to an arbitral jurisdiction is referred to as a compromis. 
insert a provision into their contract so that, in the event of a dispute, it will be subject to and resolved by arbitration, and it is generally called an arbitration clause. ${ }^{11}$ This second form of agreement is the more common source of arbitration.

In terms of content, a submission agreement is usually long, while an arbitration clause is usually short. This is not because of any particular legal requirement, it is simply a reflection of the practicalities of the situation. A submission agreement, which deals with an existing dispute, can be tailored exactly to fit the circumstances and to provide in detail how the arbitrators should deal with the dispute. An arbitration clause, which by contrast, deals with disputes which may arise in the future, does not go into too much detail, since it is not known what kind of disputes will arise and how they should best be handled. ${ }^{12}$

Not every legal system recognises agreements to arbitrate future disputes. ${ }^{13}$ Some legal systems regard arbitration agreements with suspicion; not only do the judiciary resent losing their jurisdiction to an arbitral tribunal, but they argue that agreements regarding future disputes lack 'true assent' and 'confidential trust.' ${ }^{, 14}$ The argue that assent and trust are lacking because the parties cannot immediately name an arbitrator in relation to a specific dispute. Accordingly, these legal systems only recognise a submission agreement.

Despite apprehension and uncertainty surrounding arbitration agreements dealing with a future dispute, practitioners use them extensively, both in national and international transactions. ${ }^{15}$ This is

${ }^{11}$ In civil law it is known as clause compromissoire, as apposed to the compromis.

${ }^{12}$ Although the parties to a contract may agree to an arbitration clause, the hope that there will be no disputes.

${ }^{13}$ At this stage, this attitude is to be found in some states, notably Latin American and South American countries such as Brazil. See René David, "Arbitration in International Trade”, (1985), p. 171. See also Redfern and Hunter, above n 1, 12.

${ }^{14}$ David, above n $13,12$.

${ }^{15}$ Philippe Fouchard (L'arbitrage dans le Commerce International, Vol. II, (1965)), quotes the view of a certain specialist in commercial arbitration according to which already at that time about $80 \%$ contracts in international trade contained arbitration clause. As cited by Dr. habil Tadeusz Szurski, "Arbitration Agreement and Competence of the Arbitral Tribunal", in Pieter Sanders (ed), "UNCITRAL Project for a Model Law on International Commercial Arbitration", (Deventer: Kluwer Law and Taxation Publishers, 1984), p. 55. 
due to a number of considerations. Firstly, international conventions and other international instruments recognise and support the use of submission agreements as well as arbitration clauses.

The Geneva Protocol on Arbitration Clauses 1923 (the "Geneva Protocol of $\left.1923^{\prime \prime}\right)^{16}$ provided that:

[e]ach of the Contracting States recognises the validity of an agreement, whether relating to existing or future differences, between parties subject respectively to the jurisdiction of different Contracting States. ${ }^{17}$

This Geneva Protocol of 1923 made contracting states recognise the validity of arbitration agreements referring to future disputes.

Secondly, the New York Convention of on the Recognition and Enforcement of Foreign Arbitral Awards 1958 (the "New York Convention of 1958") confirmed the principle which provides that:

[e]ach Contracting State shall recognise an agreement in writing under which the parties undertake to submit to arbitration all or any differences which have arisen or which may arise between them ... ${ }^{18}$

${ }^{16}$ Signed at Geneva, 24 September 1923, registered 28 July 1924, following its entry into enforce, published in 27 LNTS 258 (1924) n 678. See Hans Smit and Vratislav Pechota, "The World Arbitration Reporter", Vol.1, (New York: Transnational Juris Publications, Inc, Irvington-on-Hudson, 1987), p. 3.

${ }^{17}$ The Geneva Protocol of 1923, art 1. Emphasis added. This Geneva Protocol of 1923 is the first modern and genuinely international convention, which was drawn up by ICC (International Chamber of Commerce) and under the auspices of the League of Nations. It had two objective. Its first and main objective was to ensure that arbitration clauses were enforceable internationally, so the parties to any arbitration agreement would be obliged to resolve their disputes by arbitration, rather than through the courts. Its second and subsidiary objective was to ensure that arbitration awards made pursuant to such arbitration agreements would be enforced in the territory of the states in which they are made. These two objectives of the Geneva Protocol of 1923, the enforceability of arbitration agreements and awards, are also be found in a more modern version in the New York Convention of 1958 . Therefore, the Geneva Protocol of 1923 which was followed by the Geneva Convention on the Execution of Foreign Awards of 1927 (signed at Geneva 26 September 1927, in force since 25 July 1929, published in 52 LNTS 302 (1929) n 2096) is now mostly of historical interest only. However, it is useful to consider briefly as an early attempt to address the kind of problems which may arise in seeking international enforcement of arbitration agreements and awards.

${ }^{18}$ The New York Convention of 1958, art II(1). Emphasis added. 
Thus, the Geneva Protocol of 1923 and the New York Convention of 1958 requires contracting states to recognise any arbitration agreement, whether submission agreement or arbitration clause. Although these international conventions give strength to arbitration agreements, the agreements remain dependent upon national law for internal validity. As confirmed by René David, each state may freely determine who is qualified to enter into an arbitration agreement, and which matters may be referred to arbitration. ${ }^{19}$

Finally, the Model Law on International Commercial Arbitration which was adopted by the United Nations Commission on International Trade Law (the "UNCITRAL Model Law") on 21 June, 1985 defines an arbitration agreement as:

an agreement by the parties to submit to arbitration all or certain disputes which have arisen or which may arise between them in respect of a defined legal relationship, whether contractual or not. An arbitration agreement may be in the form of an arbitrationclause in a contract or in the form of a separate agreement. ${ }^{20}$

Although the UNCITRAL Model Law is still merely a proposal, it is indicative of temporary thinking and even those countries which do not adopt it in its entirety will be influenced by its principal terms, including, particularly, the general rules for both submission agreements and arbitration clauses.

\section{The Doctrine of Separability of The Arbitration Clauses}

\section{A. General}

As mentioned previously in the introduction, in reality the legal problem arises more for arbitration clauses than submission agreements which are at least physically separate contract. There is critical questions of the jurisdiction to distinguish between the agreement to arbitrate, contained in an arbitration clause, and the main contract, of which that arbitration clause forms part. An arbitration clause in a contract contemplates future disputes which may arise. By

${ }^{19}$ David, above n 13, p. 174.

${ }^{20}$ The UNCITRAL Model Law, art 7(1). Emphasis added. 
the time any such dispute arises, many events may have overtaken the main contract. It may have come to an end by performance or it may have been brought to an end prematurely by a supervening event, such as force majeure or illegality. The question is who has competence to decide that dispute? Does the arbitrator still have competence, given that his competence is derived from an arbitration clause contained in the main contract which has been overtaken by such event, to rule on that dispute? If a challenge to the jurisdiction of an arbitrator is made, by whom is the challenge to be determined? Is it to be determined by the arbitrator himself, or a court of competent jurisdiction? These questions do not lend themselves to a simple answers.

Answers to the questions above depend on the view of the two essential legal elements in an arbitration clause; firstly, whether an arbitration clause is considered as part of the main contract or as dependent agreement, or whether an arbitration clause is considered as 'separable' from the main contract or as an independent agreement, ${ }^{21}$ and secondly, whether an arbitrator has power to investigate his own jurisdiction or whether this power is inherent in the agreement to arbitrate. $^{22}$ These two legal elements are distinct, but they are interrelated. ${ }^{23}$

Traditionally, the arbitration clause has been considered as part of the contract in which it is contained ${ }^{24}$ with the result that if the validity of the main contract is challenged, the issue of the validity of the arbitration clause must be determined by the courts not by the arbitrator. ${ }^{25}$ The same rule would also apply if the issue arose in the context of a contract, initially validly concluded, which includes the arbitration clause.

${ }^{21}$ This question is referred to as the concept of separability of arbitration clause.

${ }^{22}$ As mentioned previously in the arbitral process, which is a private method of resolving disputes, the jurisdiction of the arbitrators is derived solely from the agreement of the parties.

${ }^{23}$ It is difficult to discuss them separately. The duplication and repetition in the entire discussion is, therefore, is unavoidable.

${ }^{24}$ Delaume, above n 9, p. 301.

${ }^{25}$ As stated by Lord Macmillan in Heyman v Darwins Ltd, [1942] AC 356, 371, held: 'If there has never been a contract at all, there has never been as part of it an agreement to arbitrate. The greater includes the less.' 
This traditional approach to the legal problems of an arbitration clause, particularly the latter argument, in terms of logic is plausible. ${ }^{26}$ However, it has been the object of increased criticism and appears to be rapidly falling to disfavour. ${ }^{27}$ The modern view is to consider that the arbitration clause is separable from the main contract and that if one of the contracting parties challenges the validity of the main contract, the issue ought to be determined by the arbitrator rather than the court. In other words, the competence of the arbitrator to decide all disputes, including a dispute about the validity of the main contract, between the parties would stem from the arbitration itself rather than from the contract in which the arbitration clause contained and the alleged invalidity of the contract should be subject to arbitral settlement rather than judicial determination.

\section{B. Foundations}

The doctrine of separability of an arbitration clause is both interesting in theory and useful in practice. As the arbitration clause is considered separate from the contract of which it forms part, its continuing existence is ensured when for all other purposes the contract itself is effectively at an end.

Moreover, the arbitration clause may have a separate existence not only when the main contract has come to an end by performance (that is to say, when it has been executed), but also when it has come to an end prematurely, as a result of a supervening event such as force majeure or illegality. This issue will be discussed in detail in Section 4 below. It is important in practice that an arbitration clause should be capable of this separate existence as it is the base on which the arbitration is founded. The agreement to arbitrate is contained in the arbitration clause, without such an agreement there can be no valid arbitration.

Judge Stephen M Schwebel, ${ }^{28}$ in his comprehensive essay in support of the concept of separability, reached the conclusion that the separability of an arbitration clause can be justified in four ways: first, by the intention of the parties. If they choose an arbitration clause in

${ }^{26}$ Schwebel, above n 3, p. 1-2.

${ }^{27}$ Schwebel argues that logic thought, in law, has been overcome by presumption, by practice and by necessity. Schwebel, Ibid., p. 2.

${ }^{28}$ Schwebel, Ibid., p. 3-6. 
wide terms, they intend all disputes connected with the transaction to be resolved through arbitration. They would be unlikely to intend that part of a dispute be arbitrated and part heard in the courts. Second, if a party could avoid arbitration merely by asserting that the principal agreement is invalid, it would be a very simple way to avoid arbitration or to delay the resolution of a dispute. A court would have to determine whether the contract was valid at its inception. Then the parties would need to arbitrate the rest of a dispute. The advantages of arbitration $^{29}$ would be lost. Third, as a matter of legal presumption, the parties to an agreement containing an arbitration clause conclude two agreements; first, the substantive agreement and second, the procedural agreement which is separate from the substantive agreement. Schwebel's reasoning is:

...when the parties to an agreement containing an arbitration clause enter into that agreement, they conclude not one but two agreements, the arbitral twin of which survives any birth defect or acquired disability of the principal agreement. ${ }^{30}$

Finally, without separability, a court might be required to consider the substance of the dispute. This would be necessary to determine whether an arbitrator was correct in finding that the agreement was valid and that the arbitrator had jurisdiction.

However, it is suggested that those foundations of the concept of separability of the arbitration clause are not easy to justify entirely as a matter of pure logic. This is particularly so in the case is the third foundation, that a contract which contains an arbitration clause constitutes two separate agreements. The approach taken by Schwebel is that when the contracting parties enter into a business agreement containing an arbitration clause, they enter into not one but two agreements, one regarding the business deal and other one regarding arbitration in case a dispute arises. This is in fact not a justification for the separability principle but simply a way of describing the result one wishes to reach. In other words, the true justification for this separability principle is practical rather than theoretical. ${ }^{31}$

29 The main advantage of arbitration is that it is a quick and simple method of resolving disputes, without time-consuming trouble and expense of recourse to the court.

${ }^{30}$ Schwebel, above n, p. 3, 5 . 
The theoretical problem of the third foundation, that a contract which contains an arbitration clause constitutes two separate contracts, may lead to further legal questions or more difficulties in the settlement of a dispute, for instance, in the case of assignment of contract, or novation of contract. It is possible that the parties, either assignor or assignee in case of assignment, or debtor or creditor to new debtor or new creditor in case of novation, do not mention anything about arbitration in their 'new' transaction documents, although arbitration clauses were contained in the 'old' contracts, and a dispute occurs. The question arises whether this dispute should be settled by arbitration by referring to the previous contract in which the arbitration clauses were contained.

The answer would seem to be no, whereby the main contracts and the arbitration clauses are regarded as two separate contracts. Similar legal problems may arise in the case of amendment of the main contract without providing terms of reference concerning arbitration in the amendment agreement.

In addition, in support of the twin contracts idea, theoretically, is the argument that the law applicable to the arbitration clause is not necessarily the same as the law applicable to the substance of the dispute in the main contract. In other words, it is possible to have two choices of law in a single contract containing an arbitration clause; one law governs the arbitration clause, and another law governs the main contract. ${ }^{32}$ The problem the arises: how the arbitrators should apply those two different governing laws in ruling a dispute. Even it is, theoretically, possible to have two choice of laws in the single contract, but, practically, it is likely unwise due to the difficulty in its application.

Although the foundation of twin contracts in support the concept of separability, probably, is far from the minds of the contracting parties when they sign a contract, the concept of separability itself has been widely accepted because the arbitral process would otherwise be ineffective.

${ }^{31}$ J Willis Wetter, "Salient Features of Swedish Arbitration Clauses", (Yearbook of the Arbitration Institute of the Stockholm Chamber of Commerce, 1983), p. 35.

${ }^{32}$ See in this regard, G Sauser-Hall, 'L'arbitrage en droit international privé,' Rapport et Project de Resolutions, 44 Annuaire de l'Institut de Droit International (1952), Vol. I, 558-563, as cited by Schwebel, above n 3, 6. In practice, however, it will usually be governed by the same law as that which governs the substantive rights and obligations of the parties under the main contract. See Redfern and Hunter, above n 1, p. 75. 


\section{Objectives - Advantages}

As mentioned earlier, in consensual arbitration the authority or competence of the arbitrators comes from the agreement of the parties. There is no other source from which the jurisdiction of the arbitrators tribunal can come.

Legal problems may arise in relation to the jurisdiction of an arbitrator if there is a challenge to this jurisdiction, either partial or total. ${ }^{33}$ A partial challenge raises the question of whether certain of the claims or counterclaims which have been submitted to the arbitrator are within its jurisdiction. This partial challenge does not amount to a fundamental attack on the jurisdiction of the arbitrators. A total challenge, by contrast, questions the whole basis upon which the arbitrator is acting or purporting to act.

Total challenges to jurisdiction of the arbitrator are only likely to arise in practice where the authority of the arbitrator is derived from an arbitration clause. ${ }^{34}$ An arbitrator whose authority derives from a submission agreement is unlikely to face a total challenge to his jurisdiction. The purpose of a submission agreement is to give the arbitrator jurisdiction to determine disputes between the parties. It would be perverse indeed if, having signed such an agreement, one of the parties then launched a total challenge to the jurisdiction of an arbitrator. The only issue of jurisdiction likely to arise in such circumstances will be as to whether or not a particular item of claim or counterclaim is within the scope of the submission agreement.

The grounds for a challenge to the jurisdiction of the arbitrator, then, are most often related to the basic elements of arbitration clauses. One of the alleged parties to an arbitration agreement may argue that it is not bound by the agreement, because the arbitration agreement was contained in a document which was assented to by the other party only; or he claims that the legal entity signing the agreement was a different and distinct legal person. It may be argued that the arbitration is not an agreement in writing; or that the dispute in issue is outside the scope of the arbitral agreement or not arbitrable under the applicable law. Alternatively, one of the parties may say that the claim is time barred or that for some other reason the arbitration clause is inoperative or incapable being performed.

${ }^{33}$ Redfern and Hunter, above n 1, p. 133.

${ }^{34}$ Ibid., p. 274. 
These kinds of challenge to the jurisdiction of the arbitrators raise questions as to who may decide the challenge. In other words whether an arbitrator or a court should decide the challenge and whether a ruling on jurisdiction by an arbitrator may be reviewed by a court and if so, when.

In addition, it is often the case that a plea or challenge to the jurisdiction of the arbitral tribunal is merely as a delaying tactic and obstruction of the arbitral proceedings. ${ }^{35}$ In order to avoid any attempt by a recalcitrant party to use such tactic and to obstruct the arbitral proceeding by way of pleading invalidity of the arbitration clause and to realise the advantages of commercial arbitration, ${ }^{36}$ the certainty of the legal nature of the arbitration clause, therefore, is important and necessary. ${ }^{37}$ In other words, applied correctly, the doctrines of separability and competence-competence serve to prevent bad-faith attempts, by respondents or arbitrators unduly sympathetic to them, to obstruct the arbitral proceedings. ${ }^{38}$ By establishing the doctrines of separability and competence-competence, it is likely that the main advantages of an arbitration may be reached.

In terms of the objective of the separability principle relating to the English courts, Steyn has confirmed that 'English courts have categorised and treated the arbitration clause in a contract as a wholly severable agreement for certain purposes, ie, it survives the termination of the principal contract by fundamental breach of condition or frustration. ${ }^{39}$ This view of separability is also supported

35 Aron Broches, "Commentary on the Uncitral Model Law on International Commercial Arbitration”, (Deventer: Kluwer Law and Taxation Publishers, 1990), p. 84.

${ }^{36}$ Above n. p. 29.

${ }^{37}$ As stated by Devlin that ' $[\mathrm{i}] \mathrm{t}$ is not the law that arbitrators, if their jurisdiction is challenged or questioned, are bound immediately to refuse to act until their jurisdiction has been determined by some court which has power to determine it finally.' J Devlin, Christopher Brown Ltd $v$ Genossenscshaft Oesterrichischer Waldbesitzer Holzwirtschaftsbetriebe Registrierte Genossenschaft Mit Beschrankler Haftung [1954] 1 QB 8, 12 and 13, as cited in Redfern and Hunter, above n 1, p. 275.

${ }^{38} \mathrm{~J}$ Willis Wetter, 'The Importance of Having a Connection,' (1987) 3 Arb Int'l 329, as cited in Carl M Svernlöv, 'The Evolution of the Doctrine of Separability in England: Now Virtually Complete?,' (1992) 9 Journal of International Arbitration, p. 115.

${ }^{39}$ Sir Johan Steyn and VV Veeder QC, 'England,' in Albert Jan van den Berg and Pieter Sanders (eds), "International Handbook on Commercial Arbitration", vol. I, (Deventer/Netherland: Kluwer Law and Taxation Publishers, 1988), p. 9. 
by Redfern and Hunter who said that '[i]f the main contract was valid when made but became invalid because (for example) of supervening illegality the arbitration clause may indeed survive. ${ }^{, 40}$ Mustill and Boyd add that '[a]n arbitrator can hold that the contract has been discharged by frustration or repudiation, or has been rescinded on the ground of misrepresentation or non disclosure, without casting any doubt upon his own status as arbitrator. ${ }^{, 41}$

\section{Arbitration Conventions and Rules}

This part will examine some of the most important international arbitration conventions and rules and to what extent they provide for the separability of arbitration clauses.

\section{The New York Convention of $\mathbf{1 9 5 8}$}

The New York Convention on the Recognition and Enforcement of Foreign Arbitral Awards of 1956 (the "New York Convention of $\left.1958^{\prime \prime}\right)^{42}$ is an enforcement convention aimed at national courts rather than arbitration tribunals. It has nevertheless been the subject of some discussion concerning whether it recognises the doctrine of separability.

The New York Convention of 1958 has no provision explicitly referring to separability. However, van den Berg finds it 'indifferent' to the doctrine of separability, as Article V(1) provides:

Recognition and enforcement of the award may be refused at the request of the party against whom it is

\footnotetext{
${ }^{40}$ Redfern and Hunter, above n 1, p. 216.

${ }^{41}$ Michael J Mustill and Stewart C Boyd, Law and Practice of Commercial
} Arbitration in England (London: Butterworths, 1989), p. 8. For an alternative explanation of cases in which an arbitration clause survives the main contract under English law, see also Adam Samuel, 'Separability in English Law - Should an Arbitration Clause be Regarded as an Agreement Separate and Collateral to a Contract in Which it is Contained?,' (1986), p. 3 Journal of International Arbitration, p. 95-109.

42 Adopted by the Conference on International Commercial Arbitration held at the Headquarters of the United Nations in New York from 20 May to 10 June 1958. Opened for signature 10 June 1958, entered into force 7 June 1959, published in 330 UNTS 38 (1959) n 4739. Smit and Pechota, above n 16, p. 31. 
invoked only if that party furnishes to the competent authority where the recognition and enforcement is sought proof that:

(a) The parties to the agreement ... were, under the law applicable to them, under some incapacity, or the said agreement is not valid under the law to which the parties have subjected it or, failing any indication thereon, under the law of the country where the award was made ... .

This provision refers the question of separability to municipal law. ${ }^{43}$ In this case Schwebel contends that the New York Convention of 1958 sustains separability 'by implication' as none of the exclusive grounds on which enforcement of an arbitral award may be refused refers to the invalidity of the main contract. ${ }^{44}$ Nevertheless, as the applicable municipal law may or may not provide for separability, it is possible that the application of that law may lead to the invalidity of the arbitration clause as a result of the invalidity of the main contract. ${ }^{45}$ Therefore, Van den Berg's view seems more compelling than Schwebel's and the New York Convention of 1958 must be considered neutral as to the doctrine of separability of an arbitration clause.

\section{The ICSID Convention of $\mathbf{1 9 6 5}$}

The Convention on the Settlement of International Investment Disputes between States and Nationals of Other States of 1965 (the "ICSID Convention of 1965 ") ${ }^{46}$ provides that: '[T] the judge of its own competence. ${ }^{47}$ Article 25 of the ICSID

43 Albert Jan van den Berg, "The New York Convention of 1958", (Deventer/Netherland: Kluwer Law and Taxation Publishers, Deventer/Netherlands, 1981), p. 145-46.

${ }^{44}$ Schwebel, above n 3, p. 22.

${ }^{45}$ Indeed, this is what happened in Sojuznefteexport v. JOC Oil Co, S Ct Bermuda, 16 July 1987, 2 Int'l Arb Rep 482.

${ }^{46}$ Done at Washington DC, 18 March 1968 , entered into force 14 October 1966,17 UST 1270, TIAS, n 6090, 575 UNTS 159. Smit and Pechota, above n 16, p. 74.

${ }^{47}$ The ICSID Convention of 1965, art 41(1). 
Convention of 1965 provides that the jurisdiction of the ICSID Centre under whose auspices arbitral tribunals are formed embraces any legal dispute arising directly out of an investment between a Contracting State and a national of another Contracting State which the parties consent to submit. 'When the parties have given their consent, no party may withdraw its consent unilaterally. ${ }^{48}$ This provision has been authoritatively construed to mean that a State's attempted unilateral rescission of an agreement to submit disputes for resolution by an ICSID tribunal does not impair the tribunal's jurisdiction. ${ }^{49}$ It may be argued that what a State or party cannot do directly it cannot do indirectly; that if it is not entitled to vitiate the arbitral process by withdrawing its agreement to arbitrate, it is not entitled to vitiate the arbitral process by maintaining that the principal agreement containing the arbitral obligation is void or voided.

The Arbitration (Additional Facility) Rules of ICSID explicitly provide, in Article 46, paragraph 1:

Objection to Competence

(1) The Tribunal shall have the power to rule on its competence. For the purposes of this Article, an agreement providing for arbitration under the Additional Facility shall be separable from the other terms of the contract in which it may have been included.

Thus the ICSID Additional Facility Rules expressly embody the doctrine of separability of an arbitration clause.

\section{The ICC Arbitration Rules of $\mathbf{1 9 7 5}$}

The Rules of the Court of Arbitration of the International Chamber of Commerce of 1975 (the "ICC Arbitration Rules of $\left.1975^{\prime \prime}\right)^{50}$ also embrace the principle of separability, as well as the

${ }^{48}$ The ICSID Convention of 1965 , art 25(1).

${ }^{49}$ Ibid.

50 The ICC Arbitration Rules of 1975 has been amended on 1 July 1986 and 1 January 1988. The amendments have been incorporated into the Rules, respectively concerning the cost and payment and the matters related to the constitution of the arbitral 
competence-competence of arbitration agreement. ${ }^{51}$ After making a provision for competence-competence in Article 8(3), Article 8(4) of the ICC Arbitration Rules of 1975 states that:

Unless otherwise provided, the arbitrator shall not cease to have jurisdiction by reason of any claim that the contract is null and void or allegation that it is inexistent provided that he upholds the agreement to arbitrate. He shall continue to have jurisdiction, even though the contract itself may be inexistent or null and void, to determine the respective rights of the parties and to adjudicate upon their claims. ${ }^{52}$

The scope of this Article 8(4) of the ICC Arbitration Rules of 1975 is far-reaching, providing not only for the separability of the arbitration agreement for the purposes of ruling on its validity, but also empowering the arbitrators to rule on the respective rights of the parties even after a determination that the main agreement is null and void or inexistent. The phrase 'provided that he upholds the arbitration agreement to arbitrate' in Article 8(4) implies, however, that the jurisdiction of the arbitrator ends where the invalidity runs to the arbitration clause itself. If the arbitrator cannot uphold the arbitration agreement, he has no further basis for his jurisdiction.

\section{The UNCITRAL Arbitration Rules of $\mathbf{1 9 7 6}$}

The Arbitration Rules adopted on 28 April 1976 by the United Nations Commission on International Trade Law (the "UNCITRAL Arbitration Rules of 1976") are squarely in point. It should be noted that these Rules for international commercial arbitration were recommended by the United Nations General Assembly in a resolution which characterised them as acceptable in countries with different legal system, social and economic

tribunal, such as the appointment, challenge and replacement of arbitrators. Appendix 6 in Redfern and Hunter, above n 1, p. 572.

${ }^{51}$ See generally W Laurence Craig, William W Park and Jan Paulsson, International Chamber of Commerce Arbitration, 2nd ed, (New York: Oceana Publications, Inc, 1990), p. 65-72.

52 The ICC Arbitration Rules, art 8(4). 
systems. ${ }^{53}$ Article 21(2) of the UNCITRAL Arbitration Rules expressly provides for separability of the arbitration clause. This Article states that:

The arbitral tribunal shall have the power to determine the existence or validity of the contract of which the arbitration forms a part. For the purpose of Article 21, an arbitration clause under these rules shall be treated as an agreement independent of the other terms of the contract. A decision by the arbitral tribunal that the contract is null and void shall nor entail ipso jure the invalidity of the arbitration clause.

This Article 21(2) accepts the doctrine of separability as to voidable agreements. Apparently, it also confers the arbitral tribunal the power to rule on the validity of the main contract ${ }^{54}$ and on the substantive dispute between the parties even after finding that the main contract is invalid. Unlike the ICC provision, however, it contains no limitation as to the prerequisite of finding the arbitration clause valid. Such a requirement must nevertheless be read into the Article.

\section{The UNCITRAL Model Law of $\mathbf{1 9 8 5}$}

The United Nations Commission on International Trade Law further adopted, on June 1985, the UNCITRAL Model Law on International Commercial Arbitration (the "UNCITRAL Model Law of 1985"). ${ }^{55}$ Article 16(1) of the UNCITRAL Model Law of 1985 similarly provides that:

The arbitral tribunal may rule on its own jurisdiction, including any objections with respect to the existence or validity of the arbitration agreement. For that purpose, an arbitration clause which forms part of the

\footnotetext{
${ }^{53}$ The second paragraph/consideration of the General Assembly Resolution 31/98 on 15 December 1976.

54 This authority, however, is subject to judicial control. See Pieter Sanders, 'Commentary' in Pieter Sanders (ed), (Yearbook of the International Council for Commercial Arbitration, 1977) vol II, p. 198-99.

${ }^{55}$ Adopted by the UNCITRAL on 21 June 1985, UN Doc A/40/17, 81-93. Smit and Pechota, above n 16, p. 3 .
} 
contract shall be treated as an agreement independent of the other terms of the contract. A decision by the arbitral tribunal that the contract is null and void shall nor entail ipso jure the invalidity of the arbitration clause.

This provision may seem a bit more limited than the provision in Article 21(2) of the UNCITRAL Arbitration Rules due to the wording 'an arbitration clause which forms part of the contract, ${ }^{, 56}$ but substantially the provisions are the same.

\section{E. Arbitration Cases}

This part will discuss arbitration cases, including the relevant rules, of some of the more important arbitration jurisdictions, either because of the large volume of international trading in which the country is involved, or because the jurisdiction is routinely chosen by national of other countries by virtue of the quality or accessibility of its arbitration process, namely France and the Netherlands (representing the civil law countries), the United States of America and England (representing the common law countries).

\section{France}

In France, currently, the rules concerning arbitration are divided into rules for domestic and international arbitration. ${ }^{57}$ Arbitration is international if it involves international commercial interests. ${ }^{58}$ The Code of Civil Procedure is silent on the issue of separability, but courts have recognised separability in cases concerning international arbitration. In 1963, the Court of Cassation ruled in Société Gosset v Société Carpelli ${ }^{59}$ that the arbitration clause is juridically independent and, therefore,

\section{${ }^{56}$ Ibid.}

${ }^{57}$ Rules concerning international arbitration are contained in the Code of Civil Procedure, Book IV, Titles V-VI. See generally International Chamber of Commerce, Arbitration Law in Europe (1981), p. 145-158.

${ }^{58}$ The Code of Civil Procedure, art 1492., Ibid., p. 145.

${ }^{59}$ Cour de Cassation, [1963] D Jur 545. 
unaffected by a determination that the main contract is invalid. This holding was affirmed in 1972 in Hecht v Société Buisman. ${ }^{60}$

This ruling is regularly followed, but no distinction has been made between void and voidable agreements. Exceptional circumstances may very well refer to agreements alleged never to have been entered into, but in the absence of any clarifying subsequent cases, it is impossible to confirm.

Although the doctrine of separability has not been applied in cases involving domestic arbitration, article 1466 of the Code of Civil Procedure ${ }^{61}$ may implicitly recognise the power of an arbitrator to resolve a dispute regarding the validity of the main contract. $^{62}$

\section{The Netherlands}

The Supreme Court of the Netherlands has also endorsed the separability principle. The Court held in 1963 that an arbitrator may proceed with arbitration even though the contract may be illegal unless the result would be unjust. ${ }^{63}$ Further, article 1053 of the Dutch Arbitration Act permits an arbitrator, subject to review by state courts, to rule on an allegation that the main contract is nonexistent. Article 1053 states that:

An arbitration agreement shall be considered and decided upon as an separate agreement. The arbitral tribunal shall have the power to decide on the validity of the contract of which the arbitration agreement forms part or to which the arbitration agreement is related. ${ }^{64}$

${ }^{60}$ Cour de Cassation, 4 July 1974, 99 J Droit Int'l (Clunet) 842.

${ }^{61}$ See Yves Derains, 'France,' in Albert Jan van den Berg and Pieter Sanders (eds), International Handbook on Commercial Arbitration (1984) vol I, Annex I-9. Art 1466 the Code of Civil Procedure, Book IV provides: 'If one of the parties contests, before the arbitrator, the latter's jurisdiction, whether in principle or scope, it is for the arbitrator to decide on the validity or scope of his mission'.

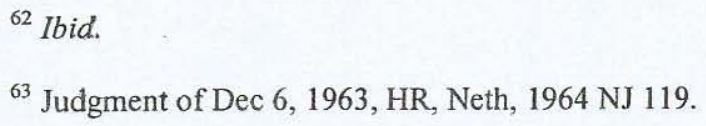


However, in case a contract cannot be concluded to have come into being at all, the separability rule cannot be deemed applicable, since nonexistence must be deemed to extend to the arbitration clause as well. In such case, an arbitral tribunal may provisionally rule the issue of nonexistence, ${ }^{65}$ but this ruling pertains to the jurisdiction and is therefore subject to review by the courts.

\section{The United States of America}

According to Nussbaum, separability had 'gained a solid footing' in the United States by $1940 .^{66}$ The courts of New York introduced the doctrine of separability in the United States during the 1930 's by authorising arbitrators to issue binding judgments on allegations that a contract containing an arbitration clause was cancelled or invalid. ${ }^{67}$ In Robert Lawrence Co $v$ Devonshire Fabrics, Inc ${ }^{68}$ it was held that separability was a rule of national substantive law and that, as federal law, separability should apply to contracts involving interstate commerce. ${ }^{69}$ Affirming this approach, the Supreme Court held in Prima Paint Co $v$ Flood \& Conklin Mfg Co, ${ }^{70}$ that Section 4 of the United States Arbitration $\mathrm{Act}^{71}$ mandates the enforcement of an arbitration clause when

${ }^{64}$ The Netherlands Arbitration Act, translated in Albert Jan van den Berg, 'The Netherlands,' in Albert Jan van den Berg and Pieter Sanders (eds), International Handbook on Commercial Arbitration (1987) vol II, Annex II-8.

${ }^{65}$ Van den Berg, Ibid., p. 8.

${ }^{66}$ Nussbaum, 'The "Separability Doctrine" in American and Foreign Arbitration," (1940) 17 NYU LQ Rev 609, 615 as cited by Anthony Gardner , 'The Doctrine of Separability in Soviet Arbitration Law: An Analysis of Sojuzneftexport v JOC Oil Co,' (1990) 28 Columbia Journal of Transnational Law, p. 312.

${ }^{67}$ Ibid., p. 614-15.

${ }^{68} 271$ F 2d 402 (2d Cir 1959).

${ }^{69}$ Although the separability doctrine continues to have a mixed reception in state courts, nearly all cases involving international commercial arbitration are litigated in federal courts. See Gardner, above n 66, p. 312.

${ }^{70} 388$ US 395, 87 SCt 1801, 18 LEd 2d 1270 (1967). 
fraud in the inducement of the contract is alleged, unless the parties intended otherwise.

Some federal courts have construed the decision in Prima Paint case to mean that the only way to strip an arbitrator of his jurisdiction is to attack the arbitration clause directly. ${ }^{72}$ Others reject separability when an arbitration clause does not repeat the formulation in Prima Paint that disputes 'arising out of or relating' to the contract shall be submitted to arbitration. For instance, in Michele Amoruso e Figli v Fisheries Development, ${ }^{73}$ the court held that an arbitration clause submitting disputes 'arising of' the contract did not authorise an arbitrator to make a binding determination about whether the contract had been fraudulently induced. Finally, the United States. federal courts generally hold that an arbitration clause is not severable when the existence of the main contract is in dispute. ${ }^{74}$

\section{England}

Courts in England regularly affirm separability except in cases involving contracts which are allegedly nonexistent or invalid $a b$ initio. The House of Lords endorsed the doctrine of separability in Bremer Vulkan Schiffbau und Maschinenfabrik $v$ South India Shipping Corporation, Inc ${ }^{75}$ a seminal case in English arbitration law. In that case, Lord Diplock declared that 'the arbitration clause constitutes a self-contained contract collateral or

${ }^{71}$ Section 4 of the US Arbitration Act says: '... The court shall hear the parties, and upon being satisfied that the making of the agreement for arbitration or the failure to comply therewith is not in issue, the court shall make an order directing the parties to proceed to arbitration in accordance with the terms of the agreement .... If the making of the arbitration or the failure, neglect, or refusal to perform the same be in issue, the court shall proceed summarily to the trial thereof. ...' See Harold M Holtzmann, 'United States' in Albert Jan van den Berg and Pieter Sanders (eds), International Handbook on Commercial Arbitration (1992) vol III, Annex I-3. (1st Cir 1985).

${ }^{72}$ See Unionmutual Stock Life Ins Co v Beneficial Life Ins Co, 774 F 2d 524, 529

${ }^{73} 499$ F Supp 1074, 1080 (SDNY 1980).

${ }^{74}$ See eg American Safety Equipment Corp v JP Maguire \& Co, 391 F 2d 821 (2d Circ CA, 1968).

${ }^{75}[1981] 1$ AC $909,980$. 
ancillary to the shipbuilding agreement itself. ${ }^{, 76}$ Wetter concluded that 'England effectively has adopted the separability doctrine.,77 Samuel, a leading English scholar, also has confirmed this conclusion, however, that separability does not apply to allegedly nonexistent contracts or contracts that are invalid $a b$ initio. In other words, the doctrine of separability of arbitration clauses in voidable contracts has been accepted in England but not in void contract. $^{78}$

However, the judgment in Paul Smith Ltd $v H \& S$ International Holdings Co Inc ${ }^{79}$ indicates that English courts may be ready to allow arbitrators to rule on the $a b$ initio validity of a contract containing an arbitration clause.

IV. The Separability: Treatment of an Arbitration Clause Contained In Contracts Alleged To Be Void Ab Initio and Nonexistent

\section{A. General}

A number of critical questions/problems of the arbitral process or the jurisdiction of the arbitral tribunal are frequently referred to the concept of competence-competence has settled. In practice, however, the question/problem persists. The defence is recurrently raised by a party seeking to avoid or frustrate an arbitration. As discussed previously the concepts of competence-competence and separability have been widely accepted.

Although the principles of competence-competence and the separability have been sustained by the international conventions and rules, in practice not all courts in many countries have adopted the present trend to consider an arbitration clause as severable from the main contract. ${ }^{80}$ This is because an arbitration agreement from which

${ }^{76}$ This view was affirmed in Paal Wilson v Partenreederei Hannah Blumenthal, [1983] 1 AC 854, p. 917.

$77 \mathrm{~J}$ Willis Wetter, The International Arbitral Process: Public and Private (Deventer: Kluwer Law and Taxation Publishers, 1979), p. 540.

${ }^{78}$ See generally Samuel, above n 41, p. 95-109.

${ }^{79}$ [1991] 2 Lloyd's Rep 127.

${ }^{80}$ David, above n 13, 192. 
the jurisdiction of the arbitrators is solely derived (not from any international source) remains dependent upon national law for internal validity. In other words, that jurisdiction itself is derived from the arbitration agreement; and the arbitration agreement can only confer powers which are permissible under the law applicable to the arbitration agreement and under the lex fori. ${ }^{81}$

The other reason is, as a matter of theory, which will be discussed in detail in the section below, the principle of the separability of an arbitration clause has not be able convince affirmatively all the questions logically raise from legal view point. ${ }^{82}$

\section{B. No Uniformity}

Although the doctrine of separability enjoys considerable international support, it is not applied uniformly. Most nations distinguish between contracts invalid $a b$ initio and contracts which are allegedly nonexistent. ${ }^{83} \mathrm{~A}$ contract is invalid $a b$ initio when, for example, it violets public policy or it is characterised by fraudulent execution or flawed formation, even though there has been 'meeting of the minds' between the contracting parties. A contract is nonexistent when, for example, there has not been a 'meeting of the minds' or when the claimant or respondent was not a party to the contract.

While most jurisdictions do not apply the doctrine of separability to nonexistent contracts, a majority consider a dispute arbitrable when it arises out of or in connection with a contract invalid $a b$ initio. According to this view, there is a logical limit beyond which separability is not theoretically justifiable. Separating an arbitration clause from an allegedly nonexistent contract strains logic, because arbitration is rooted in consent. However, if there has been a 'meeting of the minds,' there exists some agreement from which to separate an

${ }^{81}$ Normally there is no international court with compulsory jurisdiction to determine and enforce the validity of international agreement. See also Redfern and Hunter, above $\mathrm{n} 1$, 280.

${ }^{82}$ See Section III B.

${ }^{83}$ Although the distinction between invalidity $a b$ initio and supervening illegality is also widely recognised in applications of the separability doctrine, it is not important to the main argument of this note. 
arbitration clause, even when the validity of the agreement is the issue in dispute. ${ }^{84}$

For instance, while most United States courts hold that the separability does not apply to allegedly nonexistent contracts, they are split as to whether the doctrine applies to contracts invalid $a b$ initio. ${ }^{85}$ However, the Netherlands courts apply the doctrine to both contracts invalid $a b$ initio and to allegedly nonexistent contracts, subject to review by the state courts. ${ }^{86}$ In England, disputes about the existence and the initial validity of the contract fall outside the scope of an arbitration clause. ${ }^{87}$

Arbitration conventions and rules also differ in the degree to which they apply separability. The ICC Arbitration Rules of 1975 specifically permit an arbitrator to uphold his jurisdiction and make a binding award despite the alleged nonexistence of the contract in which the arbitration clause is included. Article 8(4) of the ICC Arbitration Rules declares that '[the arbitrator] shall continue to have jurisdiction, even though the contract itself may be nonexistent or null and void, to determine the respective rights of the parties and to adjudicate upon their claims and pleas. ${ }^{, 88}$ By contrast, article 21(2) of the UNCITRAL Arbitration Rules of 1976 provides that '[a] decision by the arbitral tribunal that the contract is null and void shall not entail ipso jure the invalidity of the arbitration clause. ${ }^{, 89}$ Article $16(1)$ of the UNCITRAL Model Law of 1985 repeats this language. ${ }^{90}$

${ }^{84}$ Even those jurisdiction that support separability tend not apply it when an allegation of invalidity is directed to both the contract and the arbitration clause itself.

${ }^{85}$ Cf Shawn v Kuhnel \& Assoc, Inc, 102 NM 607, 698 P 2d 880, 882 (1985) ('It is for a court to determine issues of fraud in the inducement, not an arbitrator.') with Flightways Corp $v$ Keystone Helicopter Corp, $459 \mathrm{~Pa} 660,331$ A 2d 184 (1975) ('A party who has agreed to arbitrate under a broad arbitration clause cannot escape the obligation to arbitrate by alleging that the contract is invalid $a b$ initio. ')

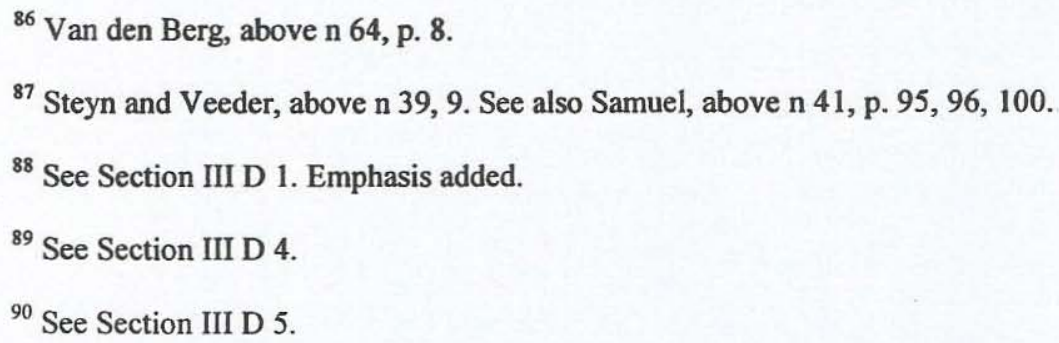

${ }^{86}$ Van den Berg, above n 64, p. 8.

${ }^{87}$ Steyn and Veeder, above n 39, 9. See also Samuel, above n 41, p. 95, 96, 100.

${ }^{88}$ See Section III D 1. Emphasis added.

${ }^{89}$ See Section III D 4.

${ }^{90}$ See Section III D 5. 


\section{The Jurisdiction and Sources of Invalidity}

Parties to arbitration agreements, seeking to remove a particular controversy from the jurisdiction of the arbitrators, have devised and invoked various objections to the validity and scope of the arbitration clause. The concepts of competence-competence ${ }^{91}$ and separability of arbitration clause have arisen to rationalise a legitimate desire by arbitrators, courts and scholars to prevent the consequences of such abuses and intolerable behaviour. ${ }^{92}$

There are two aspects to competence-competence. First, it simply means that a tribunal, be it judiciary or arbitral, is the judge of its own jurisdiction, ${ }^{93}$ and therefore has the right to rule on its own competence. The arbitrator does not have to stop the proceedings merely because his competence in challenged, but he can proceed with the arbitration and consider whether he has jurisdiction. ${ }^{94}$ Second, the arbitration agreement operates to oust the initial jurisdiction of ordinary courts. When presented with prima facie objection of the existence of an arbitration agreement, a court must refer the dispute to arbitration.

The competence-competence problem is distinct from the issue of separability. The doctrine of separability holds that the arbitration clause and the main contract are regarded as two separate agreements. The arbitration clause is separable from the rest of the contract, and an assertion that the latter is invalid does not prevent the arbitrators from ruling on the validity of the former. ${ }^{95}$ This doctrine of separability

${ }^{91}$ The principle that an arbitrator has jurisdiction to determine his own jurisdiction, also known as Kompetenz-Kompetenz in Germany or Competence de la competence in France.

${ }^{92}$ Wetter, above n 31, p. 329, 334.

${ }^{93}$ Schwebel, above n 3, p. 2.

94 Sojuznefteexport v JOC Oil Co, above n 39. The Supreme Court of Bermuda points out that the arbitral ruling on jurisdiction may be open to subsequent judicial review, either in the jurisdiction where the arbitration takes place, or when someone seeks to enforce the award.

95 Kaj Hobér, 'The Doctrine of Separability Under Swedish Arbitration Law (Including Comments on the Position of American and Soviet Law),' (1983) 68 Svensk Juristtidning, p. 257, 264, as cited in Craig, Park and Paulsson, above n, p. 51, 519. 
makes perfect sense when the arbitration agreement is, in fact, a separate document.

However, where the arbitration agreement is part of a contract, the validity of which is disputed, it would seem that the obligation to arbitrate disputes arising under the agreements is nullified, terminated or suspended ${ }^{96}$ as well, and that the arbitrators would be unable to rule on its validity.

The source of the invalidity of the contract is the determining factor in the proper application of the doctrine of separability. It is important to distinguish between (i) agreements which have been validly entered into, the continuing validity of which is disputed, ${ }^{97}$ (ii) agreements which violate public policy or which are characterised by fraudulent execution or flawed formation ${ }^{98}$ and (iii) agreements that have never been entered into. ${ }^{99}$

In the (i) category of agreements, the doctrine of separability serves the purpose outlined above; to prevent bad faith attempts by one party to obstruct the arbitral proceedings by alleging invalidity of the agreement. If the agreement was valid up until the dispute, it makes little sense to disallow the arbitral tribunal to rule on the dispute because its jurisdiction is established in the valid agreement. As discussed in the previous part the separability doctrine in terms of voidable agreements has been widely accepted in the field of international commercial arbitration. The issue of separability where the main contract is nonexistent or void $a b$ initio is discussed in the following part.

\section{Nonexistence}

The doctrines of separability and competence-competence cannot be applied in a vacuum. Therefore, no arbitration clause, regardless of its the wording, should have the power to prevent a

${ }^{96}$ Schwebel, above n 3, 1-2.

${ }^{97}$ In the interest of simplicity, agreements validly entered into whose ongoing validity is disputed will be referred to as "voidable agreements."

${ }^{98}$ Agreements for which there has been entered into whose ongoing the meeting of minds is disputed will be referred to as "void $a b$ initio agreements."

${ }^{99}$ Agreements which have not been the meeting of minds is disputed will be referred to as "nonexistent agreements." 
court from exercising jurisdiction to determine whether a contract was ever concluded. If the principal agreement was never entered into, the arbitration agreement contained therein must be affected as well. For example, a minor, not legally competent to contract, or the claimant or respondent who was not party to the contract, is also per se prevented from contracting for arbitral resolution of any dispute. As stated by Judge Schwebel:

... if the agreement was never entered into, its arbitration clause never came into force. If the agreement was not validly entered into, then, prima facie, it is invalid as a whole, as must be all of its parts, including its arbitration clause. ${ }^{100}$

The separability of an arbitration clause in an agreement alleged never to have existed has not been generally accepted in international commercial arbitration. ${ }^{101}$ and this issue must be left to the court.

\section{Void Ab Initio}

When the validity $a b$ initio of a contract is in dispute, the contractual power of the parties is not an issue. Instead, a determination is sought as to whether an existing contract should be declared void for reasons such as illegality, fraud or duress. No conceptual problem exists with submitting this determination to arbitration. According to the doctrine of separability, the arbitration clause is juridically independent of the main contract in which it appears. Therefore, an arbitrator may have jurisdiction to determine the rights and obligations of the parties even though the main contract is either invalid $a b$ initio, or moreover for voidable contracts; in which the main contract has been discharged or rescinded, or has become unenforceable for some other reason.

For example, a contracting party to an arbitration may allege that the arbitrator lacks jurisdiction because the contract is void or

${ }^{100}$ Schwebel, above n 3, 1 . Of course, nothing prevents an arbitral tribunal from deciding its own jurisdiction, but the decision may be subject to subsequent judicial review. See also Redfern and Hunter, above n 1, p. 276.

${ }^{101}$ See generally, Carl M Svernlöv, 'What Isn't Ain't: The Current Status of the Doctrine of Separability,' (1991) 8 Journal of International Arbitration 37. See Sections C and.D. 
voidable. If the contract is, in fact, void or voidable, and the applicable law does not recognise the doctrine of separability, the arbitration proceedings are terminated. ${ }^{102}$ However, if the law recognises the doctrine of separability, the arbitral tribunal will dismiss a claim that the arbitration clause necessarily shares the fate of the main contract. The arbitrator retains jurisdiction to make a binding judgment even if the contract is invalid. If the arbitrator concludes that the main contract is valid, he may proceed to examine the terms of the contract.

The doctrine of separability is rooted in the view that an arbitration clause is a distinct and clearly identifiable part of a contract. As Schwebel has pointed, '[T]he very concept and phrase "arbitration agreement" itself imports the existence of a separate or at any rate separable agreement, which is or can be divorced from the body of the practical agreement if needs be. ${ }^{, 103}$ Thus, arbitration clauses which stipulate that all disputes arising out of or in relation to the contract be submitted to arbitration implicitly endorse the separability principle, because they include disputes concerning the validity of the contract and the jurisdiction of the arbitrator.

In fact, some legal systems used to require that an agreement to arbitrate appear in a separate document signed by the contracting parties. ${ }^{104}$ However, the more commonly held view is that the independence and separability of an arbitration clause arise from the presumed intent of the parties rather than from the placement of the clause in a separate document. ${ }^{105}$ Besides furthering the intent of the parties to an arbitration, the separability doctrine also promotes the goals of both domestic and international arbitration. Parties to a contract agree to submit

102 Since State courts may lack the authority to consider commercial disputes or to compel arbitration, the termination of the proceedings may free a party of its contractual obligations. Gardner, above n 66, p. 303.

${ }^{103}$ Schwebel, above n 3, p. 21-22.

${ }^{104}$ Hobér, above n 95, p. 257, 259.

${ }^{105}$ Pieter Sanders, 'L'autonomie de la Clause Compromissoire' (Autonomy of the Arbitration Clause), in (1978) Hommage à Frédéric Eisemann, Liber Amicorum (In Memory of Frederic Eisemann) 32 (translation supplied). 
disputes to arbitration in order to avoid risking in delay, complexity and expense that often accompanies litigation. ${ }^{106}$

The doctrine of separability thus promotes the will of the contracting parties.

This objective would be vitiated if a party were free to deprive the arbitrator of his jurisdiction simply by alleging the invalidity of the arbitration clause. Although the separability minimises dilatory tactics during arbitration, it may have the paradoxical result of increasing delay if the arbitral award is later challenged before a court and reversed on the grounds that the arbitrator lacked jurisdiction. In that case, were this allegation to be considered in a court pending arbitration, fruitless litigation and unnecessary expense might be avoided.

It has also been claimed that separability is the logical result of subjecting the arbitration clause to procedural law and the main contract to substantive law. ${ }^{107}$ Critics of this view argue that the existence of two distinct legal regimes in a contract is a consequence rather than a cause of separability. ${ }^{108}$

Moreover, as the jurisdiction of an arbitrator derives ultimately from the agreement of the parties, the application of the doctrine of separability is contingent upon the wording of the arbitration clause and on the intent of the parties evidenced thereby. Therefore, there is no element of legal fiction which can subject a dispute to the exclusive jurisdiction of an arbitrator absent an express and unequivocal submission thereto, by a sufficiently wide or 'well-crafted' arbitration clause. ${ }^{109}$ Properly observed by arbitrators and courts, this principle should satisfy the concerns Wetter has raised as to poorly crafted arbitration

${ }^{106}$ See generally Section C.

${ }^{107}$ Mauro Rubino Sammartano, International Arbitration Law, (Deventer: Kluwer Law and Taxation Publishers, 1990), p. 137.

${ }^{108}$ See eg Sanders, above n 105, p. 34.

109 Wetter suggests two clauses which should suffice in this context: (1) The Uncitral Model Clause, which reads: 'Any dispute, controversy or claim arising out of or relating to this contract, or the breach, termination or invalidity thereof, shall be settled by arbitration ...'; and (2) Wetter's own definition of "dispute": 'any dispute, controversy or claim between or among the Parties arising out of or in connection with any Project Document, including but not limited to the breach, validity, interpretation and termination thereof ....' Wetter, above n 31, p. 336. 
agreements and the failure to differentiate among arbitration agreements according to their wording.

Based on the sufficient support for the arbitration clause, it is therefore difficult to understand why allowing the question of invalidity $a b$ initio to be arbitrated would constitute 'an overzealous ambition on the part of theorists and practitioners ... to seek to overextend the proper scope of a concept like separability. ${ }^{110}$ As Wetter points out, an award is void or voidable if the tribunal's finding of the existence of an arbitration agreement is erroneous. As a practical matter, there is little reason to treat a sufficiently broad arbitration clause differently from an arbitration agreement executed on a separate piece of paper; both manifest the parties' intent, at the time they enter into the arbitration agreement, to resolve disputes by arbitration. For this reason, therefore, it is submitted that the doctrine of separability should legitimately extend to cases where invalidity $a b$ initio or illegality of the contract is alleged, as long as the wording of the arbitration clause so permits.

\section{Limits of Separability}

While separating an arbitration clause from an allegedly invalid contract is practically and theoretically justifiable as a means of promoting the presumed intent of the parties to arbitrate their disputes, separating an arbitration clause from an allegedly nonexistent contract strains logic. When a contract is nonexistent, there is no consensus upon which arbitration may be based. An allegation of nonexistence, therefore, may be examined by a national court of competent jurisdiction.

Contracts that are void $a b$ initio may divided between those whose formation was faulty and those which are void because of mistake. In the case of the former, the parties arrived at a consensus but failed to consummate their agreement in a technically correct fashion. Submitting disputes as to invalid contract formation to national courts of competent jurisdiction violates the expansive wording of most arbitration clauses ${ }^{111}$ and the central purpose of arbitration. However,

${ }^{110}$ Wetter, above n 31, p. 334.

${ }^{11}$ Arbitration agreements often state that all disputes 'in connection with' or 'in relation to' the contract shall be submitted to arbitration. According to Mustill and Boyd, 
in the case of the latter, the parties failed to reach a consensus because of mutual misunderstanding. Therefore, as a contract is nonexistent and there is no ground for the arbitrator's jurisdiction to rule on a dispute, any allegation of nonexistent may be examined by a national court.

\section{Conclusion}

The doctrine of separability of an arbitration clause contained in voidable agreements is well established in international commercial arbitration. The international conventions, rules and cases, as well as national laws, and arbitral decisions, all support the principle of separability of arbitration clauses. This application of the doctrine of separability of an arbitration clause contained in a voidable agreement is to prevent bad attempts by a contracting party to obstruct the arbitral proceedings by alleging invalidity of the main agreement.

At this current stage separating an arbitration clause from an allegedly invalid contract is practically and theoretically justifiable as a means of promoting the presumed intent of the contracting parties to arbitrate their disputes. This application of separability in contracts void $a b$ initio is to further strengthen the objective and important institution of international commercial contract.

Separating an arbitration clause from an allegedly nonexistent agreement, however, strains logic because arbitration is rooted in consent. Logic demands that the doctrine of separability have defined limits. When a contract is nonexistent, there is no consensus upon which arbitration may be based, and there is no ground for the arbitrator's jurisdiction to rule on a dispute. An allegation of nonexistence, therefore, may be examined by a national court of competent jurisdiction.

'such expressions are capable of bearing, and prima facie do bear a meaning which embraces any dispute other than one which is entirely unrelated to the transaction covered by the contract.' Mustill and Boyd, above n 41, p. 119. 


\section{Bibliography}

Atiyah, Essays on Contract. Oxford: Clarendon Press, 1986.

Broches, A, Commentary on the Uncitral Model Law on International Commercial Arbitration. Deventer: Kluwer Law and Taxation Publishers, 1990.

Craig, WL, Park, WW and Paulsson, J, International Chamber of Commerce Arbitration, 2nd ed, New York: Oceana Publications, Inc., 1990.

David, R, Arbitration in International Trade. Deventer: Kluwer Law and Taxation Publishers, 1985.

Delaume, GR, Law and Practice of Transnational Contract New York: Oceana Publications, Inc., 1988.

Derains, Yves, 'France,' in Albert Jan van den Berg and Pieter Sanders (eds) International Handbook on Commercial Arbitration Vol I DeventerNetherland: Kluwer Law and Taxation Publishers, 1984.

Gardner, A, 'The Doctrine of Separability in Soviet Arbitration Law: An Analysis of Sojusneftexpport v JOC Oil Co,' (1990) 23 Columbia Journal of Transnational Law

Hobér, K, 'The Doctrine of Separability Under Swedish Law, Including Comments on the Position of American and Soviet Law,' (1983) 68 Svensk Juristtidning (Swedish Law Journal)

Holtzmann, HM, 'United States,' in Albert Jan van den Berg and Pieter Sanders (eds) International Handbook on Commercial Arbitration Vol III Deveneter-Netherland: Kluwer Law and Taxation Publishers, 1984.

Lew, JDM, 'Arbitration Agreements: Form and Character,' in Petar Šarcevïc (ed) Essay on International Commercial Arbitration London: Graham \& Trotman/Martinus Nijhoff, 1989.

Mustill, MJ and Boyd, SC, Law and Practice of Commercial Arbitration in England, $2^{\text {nd }}$ ed, London: Butterworths, 1989.

Redfern, A and Hunter, M, Law and Practice of International Commercial Arbitration, $2^{\text {nd }}$ ed. London: Sweet \& Maxwell, 1991.

Sammartano, MR, International Arbitration Law. Deventer: Kluwer Law and Taxation Publishers, 1989. 
Samuel, A, 'Separability in English Law - Should an Arbitration Clause Regarded as an Agreement Separate and Collateral to a Contract in Which it is Contained?' (1986) 3 Journal of International Arbitration

Sanders, P, 'Commentary,' in Pieter Sanders (ed) Yearbook of the International Council for Commercial Arbitration Vol II (Kluwer Law and Taxation Publishers, Deventer, 1977)

. 'L'autonomie de la Clause Compromissoire,' (Autonomy of the Arbitration Clause) in Hommage à Frédéric Eisemann, Liber Amicorum (In Memory of Frederic Eisemann) (Chambre de Commerce International, Paris, 1978)

Schwebel, SM, International Problem: Three Salient Problems (Grotius Publication Limited, Cambridge, 1987)

Smit, $\mathrm{H}$ and Pechota, V, The World Arbitration Reporter Vol I (Transnational Juris Publications, Inc, Irvington-on-Hudson, New York, 1987)

Steyn, J and Veeder, VV, 'England' in Albert Jan van den Berg and Pieter Sanders (eds) International Handbook on Commercial Arbitration Vol 1 (Kluwer Law and Taxation Publishers, Deventer/Netherlands, 1984)

Svernlov, C, 'What Isn't Ain't: The Current Status of Doctrine of Separability,' (1991) 8 Journal of International Arbitration

. 'Evaluation of the Doctrine of Separability in England: Now

Virtually Complete?'(1992) 9 Journal of International Arbitration

Szurski, hT, 'Arbitration Agreement and Competence of the Arbitral Tribunal,' in Pieter Sanders (ed) UNCITRAL Project for a Model Law on International Commercial Arbitration. Deventer: Kluwer Law and Taxation Publishers, Deventer, 1984.

Van den Berg, AJ, 'The Netherlands' in Albert Jan van den Berg and Pieter Sanders (eds) International Handbook on Commercial Arbitration Vol II Deventer-Neteherland: Kluwer Law and Taxation Publishers, 1987.

. The New York Convention of 1958 Deventer: Kluwer Law and Taxation Publishers, 1981.

Wetter, JW, 'Salient Features of Swedish Arbitration Clauses' Yearbook of the Arbitration Institute of the Stockholm Chamber of Commerce, 1983.

. The International Arbitral Process: Public and Private Deventer: Kluwer Law andTaxation Publishers, 1979. 